\title{
ORGANOLEPTIC OF FOOD PRODUCTS MADE FROM GUDE BEAN (Cajanus cajan)
}

\author{
${ }^{1}$ Alwi Smith, ${ }^{2}$ Kristin Sangur \\ ${ }^{1}$ Biology Education Study Program, Faculty of Teacher Training and Educational \\ Sciences, Pattimura University \\ *Corresponding Author: alwi.smith@gmail.com
}

\begin{abstract}
The use of local bean as an alternative food to meet the community's nutritional needs has been widely practised by society. One of the popular local beans in Kisar Island, Southwestern Maluku community, is gude bean. The people of Kisar Island have used gude beans and sweet potatoes to make traditional food, namely kolak (sweet compote), while the young pods are used as fresh vegetables. Gude bean can be used as a functional food such as gude essence, sweetened condensed milk, and soy sauce. The research objective was to determine the organoleptic assessment of food products from gude beans. Three sterile food products using gude beans were made in this research. The organoleptic tests were conducted on the Kisar community. Organoleptic panellists were fifteen (15) people originally from Kisar Island who live in Ambon city. Panellists were selected using a purposive sampling technique because they originally from Kisar Island know the nature of gude beans, like gude beans, have consumed gude beans. Descriptive analysis techniques were used as data analysis. The results showed that gude essence, milk, and soy sauce products had good taste, colour, texture, and aroma and were acceptable for consumption. This organoleptic test showed that the Kisar community could accept the gude bean food products.
\end{abstract}

Keywords: Food products, Gude Bean, Organoleptic,

\section{Introduction}

Beans (leguminosae), such as green beans, tolo beans, red beans, soybeans, peabeans, and gude beans are well known and widely used throughout Indonesia as potential food products. The use of local beans is an alternative food to meet the nutritional needs of the community. One of the local beans that is popular in the Kisar community is gude beans. The people in Kisar Island have used gude beans with sweet potatoes to make compotes, while the young pods are used as fresh vegetables. Based on this fact, gude beans have to set as a functional food. Functional food is a food that's because of its active component inside its content it can provide benefits for health, beyond the ones provided by the nutrients contained in it (Koh \& Long, 2012).

Research conducted by Sharma et al (2011), who analyzed the nutritional content of gude bean show that protein, calcium, mangan, fiber, fat and other minerals. This initial research shows that gude beans are suitable for use as a functional food. Some of the functional foods made from gude beans that can be produced are soy sauce, milk, and gude bean essence drinks.

According to Chutmanop (2008), the high carbohydrate content can be used as a substrate in the fermentation process. Therefore, gude beans can be used as soy sauce. Soy sauce is a food product that is fermented by Aspergillus mold. High protein and mineral content can be used as vegetable milk. Grains that are processed into milk will increase the digestibility of these grains, thereby improving nutritional quality (Ariyanto, et al., 2015; Wardani, et al., 2013).

Received December $20^{\text {th }} 2020$, Revision January $31^{\text {st }} 2021$, Accepted for publication February $24^{\text {th }} 2021$. Copyright (C) 2021 Published by FKIP - Unpatti, ISSN 2721-3110 
In addition to gude-based milk, the carbohydrate and dietary fiber content in gude beans can also be processed into gude bean essence drinks. Peanut essence drinks have been in great demand by the public, one of which is green bean essence. According to Astawan (2009), green beans can be processed into nutritious and delicious drink essences. Meanwhile, according to Sa'adah and Estiasih (2015) the manufacture of this essence drink aims to increase storage resilience and diversify fruit products. Therefore, the processing of gude bean essence drinks can increase storage capacity and become an alternative to diversified foods

Several studies on the use of food ingredients as alternative functional food products have also been carried out previously such as (1) Kamsina's (2014) research on the effect of fruit essence concentrates and sugar types on the quality of functional drinks from yam (Pachyrhizus erosus) concluded that the concentration and type treatment sugar affects the quality of functional fruit essence. (2) Destro et al (2019) regarding the effect of using brown sugar types and fermentation time on water kefir characteristics concluded that the treatment of giving brown sugar affects the chemical and organoleptic properties of water kefir. (3) Research by Lyu (2017) reports that sucrose solutions can affect the texture of a product such as peach chips. (4) Fadel and Farouk (2002) reported that sugar can affect the color and taste of sweetened condensed milk due to caramelization

Gude beans, which are used as an alternative functional food that produces several food products, namely soy sauce, sweetened condensed milk, and essence made from gude beans from Southwest Maluku, are new innovations that are not well known by the public so that these products need to be tested sensory or organoleptically. . Organoleptic tests include texture, aroma, color, and taste of several functional food products made from gude beans from Southwest Maluku. Organoleptic testing of a food or beverage product can be done through the hedonic or liking test, the hedonic test includes the level of liking for the texture, aroma, color, and taste of a food or beverage product (Palczak, et al 2019). The processed food made from gude beans is the result of processed renewable products in the food sector, therefore organoleptic testing of texture, aroma, color, and taste is important for each product so that people who later as consumers can determine and evaluate the products produced from gude's bean. The results of this analysis can be used as a reference for the utilization of gude beans to be more economical and nutritious, and the community can also accept this gude bean food product. Therefore, the aim of the study is to determine the organoleptic assessment of food products from gude beans.

\section{Method}

This research was conducted from September to November 2019 with the sampling location in Romleher Utara hamlet, Wonreli Village, Kisar Island, Southwest Maluku Regency. The location for the manufacture of gude bean food products is in the Basic Biology Laboratory of the Pattimura University in Ambon. The location for organoleptic testing is at the Teacher Training and Education Faculty, Biology Education Study Program, Ambon University of Pattimura.

The tools used in this research are stoves, pans, stainless steel basins, silk, knives, spoons, measuring cups, beaker glasses, scales, blenders, aluminum foil, gauze, filters, coffee paper, trays, glass bottles, napkins. , oven and the materials used in this study were gude beans, aspergillus yeast, aqua, coconut sugar, granulated sugar, palm sugar, pandan

Received December $20^{\text {th }} 2020$, Revision January $31^{\text {st }} 2021$, Accepted for publication February $24^{\text {th }} 2021$. Copyright (C) 2021 Published by FKIP - Unpatti, ISSN 2721-3110 
leaves, and cooking spices such as lemongrass, bay leaves, lime leaves, galangal, kluwak, and star anise.

The working method for each food product is divided into several stages, for the processing of soy sauce products made from gude beans, adapted from the research of Kataoka (2005) with processing procedures starting with (1) making koji, namely gude beans soaked with aqua dest for one night, then drained and sterilized at $121 \mathrm{oC}$ for 20 minutes. After chilling, gude beans weighing $400 \mathrm{~g}, 600 \mathrm{~g}$, and $8000 \mathrm{~g}$, respectively, were inoculated with $0.3 \%$ yeast and incubated at room temperature. On day 2 , the material that has begun to overgrow with mold (Aspergillus sp.) is turned or mixed by shaking and incubation and is continued until day 3. (2) Making moromi, namely gude beans that have been overgrown with mold or koji soaked in a salt solution $(\mathrm{NaCl}) 20 \%$. At this stage, Pediococcus halophyllus was added then incubated at room temperature for 2,3 , and 4 weeks.

The processing of sweetened condensed milk products was adapted from research by Latuhaimallo, et al. (2019) with the processing procedure starting with (1) Sorting, to select good quality gude beans. (2) Washing, to remove the dirt attached to the gude beans. (3) Milling, carried out with water with a ratio of 1: $6(\mathrm{w} / \mathrm{v})$, using this ratio will produce a thickness like a cow's milk and will also get high milk protein. (4) Filtering, to obtain gude bean extract. This filtrate will later become gude bean milk. (5) Treatment of sugars (fructose, glucose, and sucrose) with concentrations of $30 \%, 40 \%$, and $50 \%$ (adapted from research by Rahman and Triyono, 2011). (6) Heating carried out in the final process of making milk to kill all pathogenic organisms and some of the existing microorganisms so as not to change the taste or composition.

The processing of essence beverage products was adapted from research by Girard dan Fukomoto (2000) with the following steps: Gude bean seeds are sorted, washed, blended, then sieved using a 60 mesh sieve. $500 \mathrm{~g}$ of gude seed flour is added with $250 \mathrm{ml}$ of water, homogenized, then filtered, then added as much sugar $(20 \%, 15 \%$, and $10 \%)$ and $\mathrm{CMC}$ as a $1 \%$ stabilizer and the addition of pandan leaves for fragrance. The next step is to cook gude bean essence at 900C for 15-20 minutes and put it directly in a sterile cup (Sa'adah and Estiasih, 2018). After chilling the samples were stored in a refrigerator at 50C for 4-6 hours, before being analyzed the samples were shaken to make them homogeneous.

After all the products are ready, the next process is to do the organoleptic test. Organoleptic tests were done on 15 semi-trained panelists. The selection of panelists using the purposive sampling technique provided that the panelists are original people of kisar or kisar derivatives, have consumed gude beans, know the characteristics of gude beans well, age ranges from 20-50 years. Organoleptic tests include texture, aroma, color, and taste of several functional food products made from gude beans from Southwest Maluku. The results of the study included organoleptic data which were then analyzed descriptively using the graphic presentation.

\section{Results and Discussion}

\subsection{Gude Bean Based Product}

Gude beans from Southwest Maluku have a high nutritional content so they can be used as an alternative functional food that can produce several food products such as soy sauce, sweetened condensed milk, and essence drinks which are new innovations that also

Received December $20^{\text {th }} 2020$, Revision January $31^{\text {st }} 2021$, Accepted for publication February $24^{\text {th }} 2021$. Copyright (C) 2021 Published by FKIP - Unpatti, ISSN 2721-3110 
have high economic value and are good for consumption. The resulting gude bean essence product is a product produced with the treatment of different types of sugar, namely sugar cane, palm sugar, and coconut sugar, the resulting sweetened condensed milk product is a product with variations in the addition of $25 \%, 35 \%$, and $45 \%$ sugar while for the product The resulting soy sauce is a product with variations in the addition of $150 \mathrm{gr}, 300 \mathrm{gr}$, and $450 \mathrm{gr}$ gude beans. The results of the three alternative functional food products can be seen in Figure 1 below:

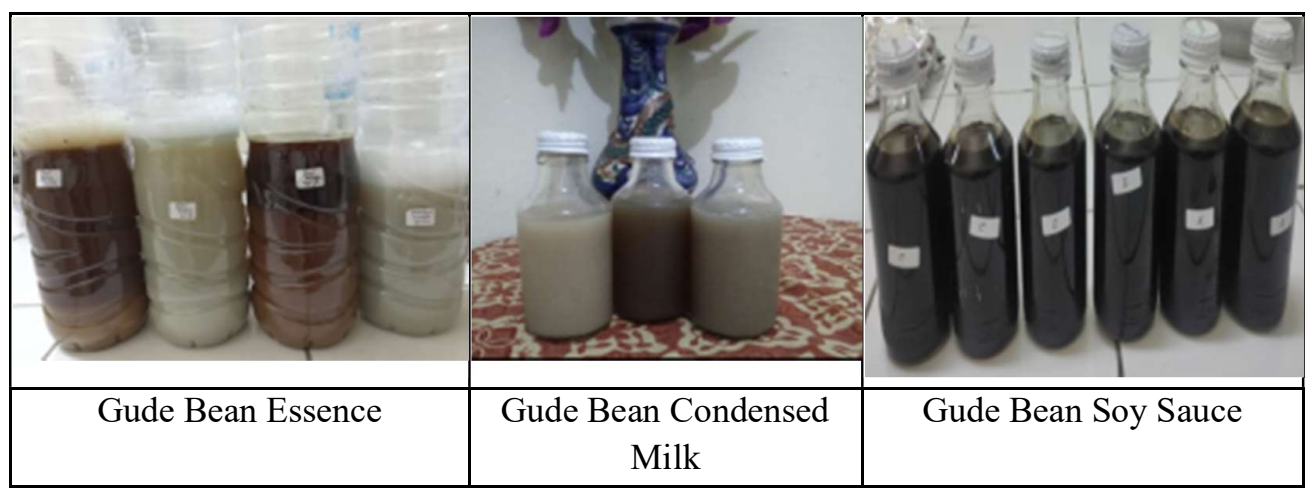

Figure 1. A product made from gude beans consisting of essence, sweetened condensed milk (SKM) and soy sauce

\subsection{Gude Bean Essence Organoleptic Test}

The results of the organoleptic test included an assessment of the texture, aroma, color, and taste of gude bean essence from Southwest Maluku with various types of sugar treatment, each of which was cane sugar, palm sugar, and coconut sugar.

\section{ORGANOLEPTIK SARI KACANG GUDE}

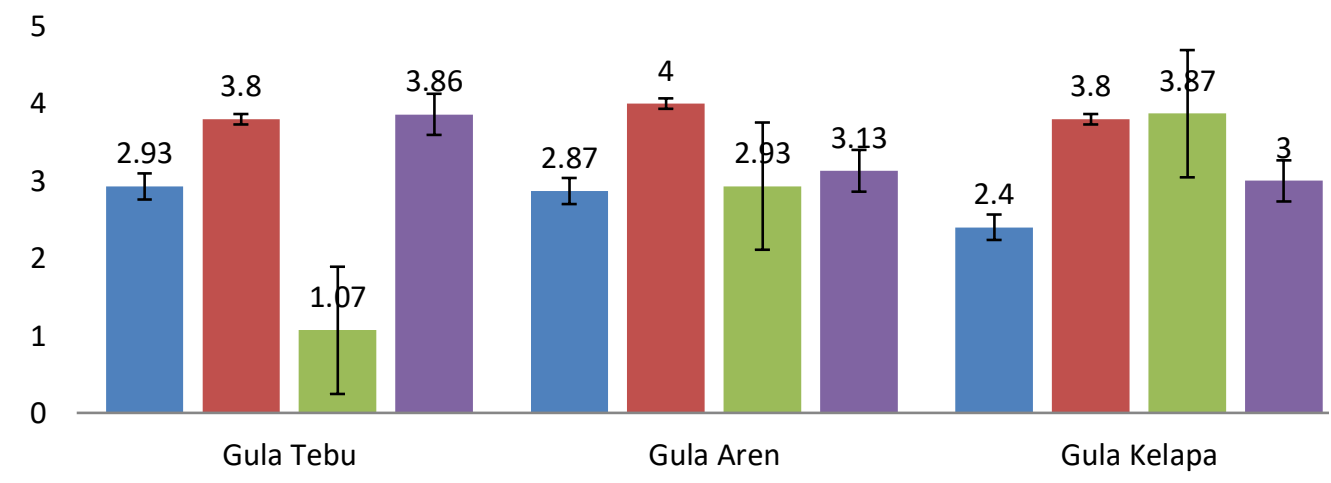

Figure 2. Variations in the Treatment of Sugar Types on the Organoleptic Value of Gude Nut-Based Essence from Southwest Maluku

The variation in the addition of sugar cane has a texture value of 2.93 beans essence, the variation in the addition of palm sugar has a texture value of 2.87 , the two additions to this type of sugar have a texture that is liquid, and for the variation, in the

Received December $20^{\text {th }} 2020$, Revision January $31^{\text {st }} 2021$, Accepted for publication February $24^{\text {th }} 2021$. Copyright (C) 2021 Published by FKIP - Unpatti, ISSN 2721-3110 
addition of coconut sugar, the resulting texture value is 2.4 with the texture is less liquid ( Figure 2).

Texture can be defined as a sensory image of a product structure that is part of the pressure reaction. Measured as mechanical force (such as hardness, adhesive and cohesiveness, viscosity, elasticity, and crispness) by kinesthetic nerves in the muscles of the hands, fingers, tongue, teeth, and lips. It can also be in the form of tactile sensory nerves, which are measured as geometric particles (crystalline, grain, sticky) by the skin of the hands, lips, and tongue (Meilgaard, Civille \& Thomas, 1999). The overall texture of gude bean essence with the addition of various types of sugar treatment resulted in different textural differences. Based on the results of observations made on gude bean essence, it is known that the resulting texture is liquid and less liquid. The liquid texture of the bean essence is caused by the addition of water to the essence which acts to homogenize sugar and bean essence. The addition of sugar types also affects the texture of bean essence, where the addition of sugar plays a role in binding or attracting pectin molecules (Indriaty \& Assah, 2015).

The variation in the addition of cane sugar and coconut sugar has an aroma value of 3.8, while the variation in the addition of palm sugar has an aroma value of 4 (Figure 2). This means that the aroma produced by the addition of sugar cane, coconut, and palm sugar is not unpleasant. According to de Mann (1989), in the food industry, aroma or odor testing is considered important because it can provide an assessment of the related product whether or not a product is accepted quickly. The appearance of this aroma or smell is because the odor is volatile (easy to evaporate) which is released from the product in the mouth or the smell is often referred to as the smell of food ingredients.

Gude beans have a distinctive aroma that is not too unpleasant, resulting in bean essence which does not smell unpleasant either. To neutralize unpleasant odors in food processing, certain ingredients can be added (Zhu, 2014). The addition of sugar cane, coconut, and palm sugar as natural fragrances is thought to have played a role in producing an unpleasant aroma in gude bean essence.

The variation in the addition of cane sugar has a color value of 1.07. This means that the color of the bean essence is not brown. The variation in the addition of palm sugar has a color value of 2.93 which means it is brown; while the variation in the addition of coconut sugar has a color value of 3.87 which means very brown (Figure 2). The overall color of gude bean essence with the addition of various types of sugar treatment resulted in different color differences. The difference in the resulting brown color is caused by the addition of the type of sugar which affects the color of the bean essence. Here the sugar cane which has a distinctive white slightly yellowish color produces a juice color that is not brown, the addition of palm sugar produces a brown color in the bean essence due to palm sugar which has a distinctive brown color, and the addition of coconut sugar type results in a color organoleptic value which is very brown due to the color of coconut sugar which has a distinctive dark brown color.

The brown color produced in gude bean juice is also influenced by the natural color of the gude beans which has a blackish-brown color, which affects the color of the gude

Received December $20^{\text {th }} 2020$, Revision January $31^{\text {st }} 2021$, Accepted for publication February $24^{\text {th }} 2021$. Copyright (C) 2021 Published by FKIP - Unpatti, ISSN 2721-3110 
bean juice. Gude beans contain flavonoids which are quite high. Flavonoids are secondary metabolites of polyphenols that are found widely in plants and food and have various bioactive effects including anti-viral and anti-flammable properties (Qinghu, 2016).

Flavonoids in plants including gude beans play a role in giving color, flavor to seeds, flowers, and fruit and aroma so that the color produced in gude bean juice is a brown color which also comes from the natural color of gude beans (Mierziak et al., 2014).

The variation in adding sugar cane has a resulting taste value of 3.86 which means very sweet, while the variations in the addition of palm sugar and coconut sugar each have a taste value of 3.13 and 3, the two additions of this type of sugar produce a sweet taste (Figure 2). Taste is the most important parameter in consumer acceptance of a product. Taste differs from the smell and involves more of the senses of the tongue. Taste is influenced by several factors, namely chemical compounds, concentration temperature, and interactions with other taste components (Jiménez-Sánchez, 2017). The difference in taste is caused by the addition of sugar which affects the taste of the bean essence. According to Cantin et al (2009), the levels of simple sugars such as saccharose, glucose, and fructose in each fruit vary widely. Sugar cane and palm fruit sugar levels are higher than coconut sugar. Sucrose in everyday life is known as sugar and is produced in plants by condensing glucose and fructose. Sucrose is found in vegetables and fruits, such as sugar cane and palm sugar, which contain relatively large amounts of sucrose compared to coconut.

Sugar plays a very large role and function in the beverage industry. This is supported by Dhartiben \& Aparnathi's research (2017) that sucrose is a chemical compound that has a sweet taste, is white, and is water-soluble. The main function of sucrose as a sweetener contains an important role because it can increase the taste reception of food.

\subsection{Condensed Milk Organoleptic Test}

The results of the organoleptic test included an assessment of the texture, aroma, color, and taste of sweetened condensed milk made from gude beans from Southwest Maluku with various treatments of adding sugar to $25 \%, 35 \%$, and $45 \%$.

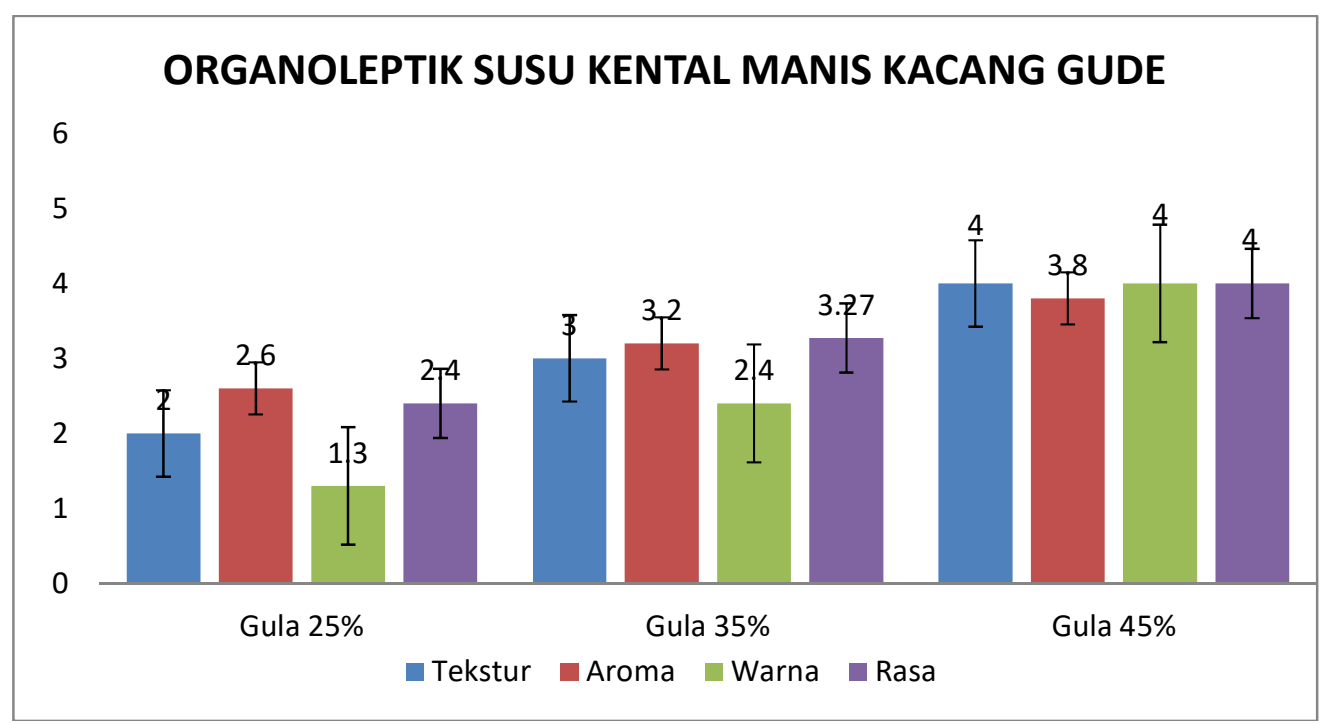

Figure 3.Treatment of Sugar Variations on Organoleptic Value of Sweetened Condensed Milk Made from Gude Beans from Southwest Maluku

Received December $20^{\text {th }} 2020$, Revision January $31^{\text {st }} 2021$, Accepted for publication February $24^{\text {th }} 2021$. Copyright (C) 2021 Published by FKIP - Unpatti, ISSN 2721-3110 
The variation of the addition of $25 \%$ sugar has a texture value of sweetened condensed milk produced by 2 which means it is less thick. The variation of the addition of $35 \%$ sugar has a texture value of 3 which means thick, while the variation of the addition of $45 \%$ sugar has a texture value of 4 which means it is very thick ( Figure 3 ). The difference in texture produced by sweetened condensed milk made from Gude bean is caused by the addition of sugar with different variations. The addition of sugar affects the texture of the resulting sweetened condensed milk where the addition of sugar plays a role in binding or attracting pectin molecules (Indriaty \& Assah, 2015).

The more sugar concentration is added, it will increase the total sugar available because the total value of dissolved solids is higher so that it has an impact on the shape or texture of sweetened condensed milk made from gude beans, the added sugar is a type of sucrose sugar which is composed of glucose and fructose. Very easily dissolved in water (Mursalin et al, 2019).

The variation in the addition of $25 \%$ sugar has an aroma value of sweetened condensed milk of 2.6 which means it is rather unpleasant, the variation of the addition of $35 \%$ sugar has an aroma value of 3.2 which means less unpleasant, while the variation of the addition of $45 \%$ sugar has an aroma value of 3.8 which means it is not unpleasant (Figure 3).

The aroma of a food product can be assessed by smelling the smell produced from the product. The food industry considers aroma to be very important in the test because it can provide an assessment of its production, adding the role of aroma in food products is as important as color because it will determine consumer acceptance. (Kuhn, 2006).

Gude beans have a distinctive aroma, which is rather unpleasant. To neutralize unpleasant odors in a food processing, certain ingredients can be added. The addition of water and sugar to gude bean essence is also able to neutralize the unpleasant aroma of sweetened condensed milk made from gude beans (Yohana, 2016).

The variation in the addition of $25 \%$ sugar has a color value of 1.3 which means it is not brown, the variation of the addition of 35\% sugar has a color value of 2.4 which means a little brown, while the variation of the addition of $45 \%$ sugar has a color value of 4 which means very brown (Figure 3 ). The difference in the resulting brown color is caused by the addition of sugar variations that affect the color of sweetened condensed milk, where the more sugar is added, the darker the resulting color will be. With the increase of sugar added to sweetened condensed milk made from gude beans from Southwest Maluku will resulted in the sweetened condensed milk turning brown. The color change is caused by the caramelization reaction. During the cooking process the main damage occurs to the sugar and the color change that occurs is caused by a caramelization reaction, namely a non-enzymatic browning reaction which includes the degradation of sugar without amino acids if the sugar is heated above its melting point so that the original color of the fruit after cooking will change color (Desrosier, 2008). Seo, et al (2004) also states that when sugar is heated continuously until the temperature exceeds its melting point, a caramelization process will occur. This formation of caramel can enhance the flavor and color of the food.

The variation in the addition of $25 \%$ sugar has a value of 2.4 which means it is rather sweet, the variation of the addition of $35 \%$ sugar has a value of 3.27 which means sweet, while the variation of the addition of $45 \%$ sugar has a value of 4 which means very sweet. Taste is one of the parameters that greatly determine consumer acceptance of the products produced (Fitri, 2017). The overall taste of gude bean essence with the treatment of adding different sugars produces different flavors. The higher the concentration of sucrose added, the higher the sweetness produced by sweetened condensed milk made from

Received December $20^{\text {th }} 2020$, Revision January $31^{\text {st }} 2021$, Accepted for publication February $24^{\text {th }} 2021$. Copyright (C) 2021 Published by FKIP - Unpatti, ISSN 2721-3110 
gude beans. Sucrose which acts as a sweetener can increase the acceptance of food by masking the bad taste. Sucrose also strengthens the taste of sweetened condensed milk made from gude beans because it can suppress the distinctive and unpleasant taste found in gude bean essence. Other flavor components will interact with the primary flavor components. The result may be an increase in taste intensity or a decrease in taste intensity (taste compensation).

\subsection{Soy Sauce Organoleptic Test}

Organoleptic test results include assessment of texture, aroma, color and taste of soy sauce made from gude beans from Southwest Maluku with variations in the addition of $150 \mathrm{gr}, 300 \mathrm{gr}$ and $450 \mathrm{gr}$ gude beans.

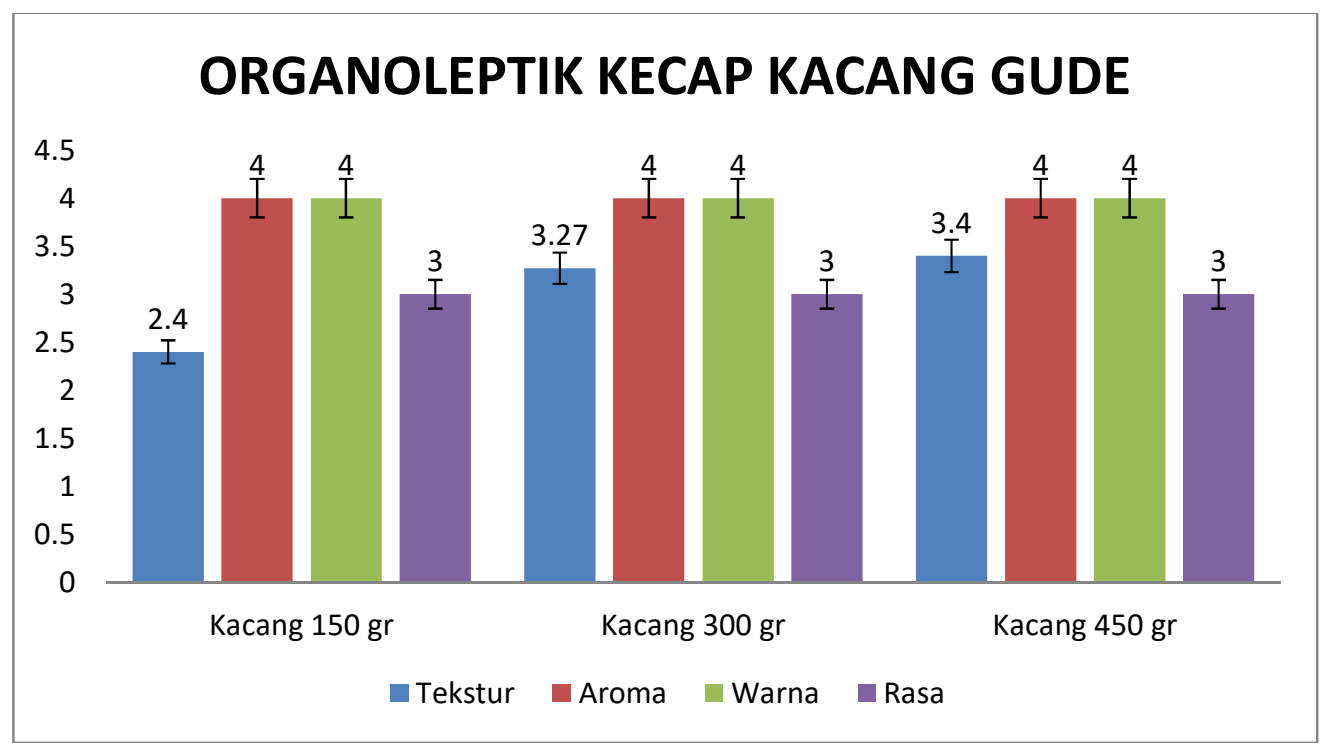
Figure 4.Treatment of Gude Beans Variations on Organoleptic Value of Soy Sauce
Made from Gude Beans from Southwest Maluku

The variation of the addition of $150 \mathrm{gr}$ gude beans has a soy sauce texture value of 2.4 which means it is slightly thick, the variations in the addition of $300 \mathrm{gr}$ and $450 \mathrm{gr}$ gude beans respectively have a texture value of 3.27 and 3.4 which means thick. The difference in texture produced by sweetened condensed milk made from gude peabeans is caused by the addition of different variations of gude beans. The addition of gude bean juice affects the texture of the resulting soy sauce, the more the concentration of gude beans increases, the resulting texture of gude bean-based soy sauce will be thicker.

Variations in the addition of 150gr, 300gr, and 450gr gude beans each have an aroma value of 4 , which means they are very fragrant. The aroma is an attribute that is analyzed by panelists' senses of smell based on the interests and goals of product sales. The very fragrant aroma of soy sauce products is also produced by the kitchen spices added to soy sauce such as lemongrass, galangal, lime leaves, star anise, bay leaves, and kluwak, the addition of sugar can also mask the unpleasant smell of gude beans. The aroma that is formed in the product is caused because the aroma is a volatile compound that can react with the olfactory nerves (Tressl and Jennings, 1972).

Received December $20^{\text {th }} 2020$, Revision January $31^{\text {st }} 2021$, Accepted for publication February $24^{\text {th }} 2021$. Copyright (C) 2021 Published by FKIP - Unpatti, ISSN 2721-3110 
Variations in the addition of 150gr, 300gr, and 450gr gude beans each have an aroma value of 4 which means very black. The very black color is formed when the moromi fermentation takes place, the color of the soy sauce solution is formed as a result of the browning reaction between the reducing sugar and the amino groups of the protein. In addition, the presence of kluwak and the addition of sugar also produces a distinctive color of soy sauce after the cooking process. Color is one of the important characteristics of soy sauce because it is related to the flavor that is formed (Devanthi \& Gkatzionis, 2019).

Variations in the addition of $150 \mathrm{gr}, 300 \mathrm{gr}$, and $450 \mathrm{gr}$ gude beans each have an aroma value of 3 , which means it is sweet. Taste can be judged by a chemical response by the taste buds. Taste is a very important factor in determining a consumer's final decision to accept or reject a food product. The taste compounds in the product can stimulate the senses of the recipient. Taste is influenced by several factors, namely chemical compounds, temperature, concentration, and interactions with other taste components (Lioe et al., 2010; Gao et al., 2019; Yanfang \& Wenyi, 2009)

The sweet taste is caused by the addition of sugar in soy sauce made from gude beans (Diez-Simon, 2020). Sugar is a sweetener that is used to give flavor and is also used to neutralize or mask the unpleasant smell of gude beans. Another factor that also affects the taste quality of soy sauce is fermentation. During the fermentation process of the molds, the molds release enzymes that break down the substrate into dissolved compounds, the levels of these dissolved compounds determine the taste of soy sauce. Moromi fermentation will produce peptide amino acids and organic acids which play a role in enriching the flavor and aroma (Zhao, et al 2016).

\section{Conclusion}

Based on the research results, it can be concluded that gude beans can be used as functional food in the form of beans essence, sweetened condensed milk, and soy sauce. The organoleptic results show that the three products are acceptable in society with their distinctive aroma, sweet and very sweet taste, black color, liquid essence texture, sweetened condensed milk and thick and very thick soy sauce.

\section{Acknowledgements}

Researchers would like to thank the Faculty of Teacher Training and Education, Pattimura University for providing research funding through Applied Research for the 2020 fiscal year with No SK. 1580 / UN13 / SK / 2020 dated 10 August 2020.

\section{REFERENCES}

Ariyanto, N. O., Wiyanto, S. D., Hindarso, H., Aylianawati. 2015. Pengaruh rasio massa biji dan volume air dan suhu ekstrakasi terhadap ekstraksi biji-bijian dalam pembuatan susu nabati. [The Effect of Seed Mass Ratio and Water Volume and Extraction Temperature on Grain Extraction in Making Vegetable Milk]. Jurnal Ilmiah Widya Teknik 14 (1): 20-25.

Received December $20^{\text {th }} 2020$, Revision January $31^{\text {st }} 2021$, Accepted for publication February $24^{\text {th }} 2021$. Copyright (C) 2021 Published by FKIP - Unpatti, ISSN 2721-3110 
Chutmanop, J., Chuichulcherm, S., Chisti, Y., \& Srinophakun, P. 2008. Protease production by Aspergillus oryzae in solid-state fermentation using agroindustrial substrates. Journal of Chemical Technology \& Biotechnology: International Research in Process, Environmental \& Clean Technology, 83(7), 1012-1018.

Cantín, C. M., Gogorcena, Y., \& Moreno, M. Á. 2009. Analysis of phenotypic variation of sugar profile in different peach and nectarine [Prunus persica (L.) Batsch] breeding progenies. Journal of the Science of Food and Agriculture, 89(11), 1909-1917.

Destro, T. M., Prates, D. D. F., Watanabe, L. S., Garcia, S., Biz, G., \& Spinosa, W. A. 2019. Organic brown sugar and jaboticaba pulp influence on water kefir fermentation. Ciência e Agrotecnologia, 43: 1-17. http://dx.doi.org/10.1590/14137054201943005619

Devanthi, P. V. P., \& Gkatzionis, K. (2019). Soy sauce fermentation: Microorganisms, aroma formation, and process modification. Food Research International, 120, 364-374.

Dhartiben, B. K., \& Aparnathi, K. D. (2017). Chemistry and use of artificial intense sweeteners. International Journal of Current Microbiology and Applied Sciences, 6(6), 1283-1296.

Desrosier, NW 2008. Food Preservation Technology. M. Muljohardjo translation. University of Indonesia Press. Jakarta.

Diez-Simon, C., Eichelsheim, C., Mumm, R., and Hall. R.D. 2020. Chemical and Sensory Characteristics of Soy Sauce: A Review. Journal of Agricultural and Food Chemistry, 68:11612-11630.

Fadel, H. H. M. and Farouk, A. 2002. Caramelization of maltose solution in presence of alanine. Amino Acids, 22: 199-213.

Gao, X., Zhang, J., Liu, E., Yang, M., Chen, S., Hu, F., Ma, H., Liu, Z., \& Yu, X. 2019. Enhancing the taste of raw soy sauce using low intensity ultrasound treatment during moromi fermentation. Food chemistry, 298, 124928.

Girard, B., \& Fukumoto, L. R. 2000. Membrane processing of fruit juices and beverages: a review. Critical Reviews in Food Science Nutrition, 40(2), 91-157.

Indriaty, F. and Assah, F. Y. 2015. Pengaruh penambahan gula dan sari buah terhadap kualitas minuman serbuk daging buah pala. [The effect of addition of sugar and fruit juice on the quality of powder beverage of pala fruit powder]. Jurnal Penelitian Teknologi Industri. 7(1): 1-12.

Jiménez-Sánchez, C., Lozano-Sánchez, J., Segura-Carretero, A., \& Fernández-Gutiérrez, A. 2017. Effect on composition, phytochemical content, and physicochemical, rheological, and organoleptic properties of fruit juices. Critical reviews in food science and nutrition, 57(3), 637-652.

Kühn, J., Considine, T., \& Singh, H. 2006. Interactions of milk proteins and volatile flavor compounds: implications in the development of protein foods. Journal of Food Science, 71(5), 72-82.

Kataoka, S. 2005. Functional effects of Japanese style fermented soy sauce (shoyu) and its components. Journal of bioscience and bioengineering, 100(3), 227-234.

Koh, S.P., and long, K. 2012. Comparison of physical, chemical and functional properties of broken rice and breadfruit starches against cassava starch. Journal of Tropical Agriculture and Food Science, 2012, 40(2): 211-219.

Kamsina. 2014. Pengaruh konsentrasi sari buah dan jenis gula terhadap mutu minuman fungsional dari bengkuang (Pachyrhizus erosus). [The Effect of Concentration of Fruit Juice and Sugar Type on Quality of Functional Drinks of Jicama (Pachyrhizus erosus)]. Jurnal LITBANG Industri. 4(1): 11-18.

Latuihamallo, Y., Watuguly, T., and Tuapattinaya, P. 2019. Kualitas susu berbahan dasar biji lamun jenis Enhalus acoroides: Penentuan nilai viskositas dan pengujian sifat mikrobiologi di laboratorium. [Quality of Milk Made from Seagrass Seeds Enhalus

Received December $20^{\text {th }} 2020$, Revision January $31^{\text {st }} 2021$, Accepted for publication February $24^{\text {th }} 2021$.

Copyright (C) 2021 Published by FKIP - Unpatti, ISSN 2721-3110 
acoroides: Determination of Viscosity Value and Testing of Microbiological Properties in the Laboratory]. BIOPENDIX, 5 (2), 119-129.

Lioe, H. N., Selamat, J., \& Yasuda, M. 2010. Soy sauce and its umami taste: a link from the past to current situation. Journal of Food Science, 75(3), 71-76.

Lyu, J., Yi, J., Bi, J., Chen, Q., Zhou, L., \& Liu, X. 2017. Effect of sucrose concentration of osmotic dehydration pretreatment on drying characteristics and texture of peach chips dried by infrared drying coupled with explosion puffing drying. Drying Technology, 35(15), 1887-1896.

Meilgaard, M., Civille G, V., Carr B, T. 1999. Sensory Evaluation Techniques. CRC Press, Boca Raton.

Mierziak J., Kostyn K., and Kulima, A. 2014. Flavonoids as important molecules of plant interactions with the environment. Molecules. 19: 16240-16265.

Mursalin, M., Nizori, A., \& Rahmayani, I. 2019. The Effect Of Sugar Concentration on the Organoleptic Quality of Liberika Tungkal Jambi Instant Coffee. Indonesian Food Science \& Technology Journal, 3(1), 10-12.

Palczak, J., Blumenthal, D., Rogeaux, M., \& Delarue, J. 2019. Sensory complexity and its influence on hedonic responses: A systematic review of applications in food and beverages. Food Quality and Preference, 71, 66-75.

Qinghu, W., Jinmei, J., Nayintai, D., Narenchaoketu, H., Jinging, H., Baiyinmuqier, B. 2016. AntiInflammatory Effects, Nuclear Magnetic Resonance Identification And High Performance Liquid Chromatography Isolation Of The Total flavonoids From Artemisia Frigida. Journal Of Food And Drug Analysis, 24, 385-391.

Rahman, T., and Triyono, A. 2011. Pemanfaatan kacang hijau (Phaseolus radiatus L) menjadi susu kental manis kacang hijau. [Utilization of Mung Beans (Phaseolus radiatus L) into Mung Bean Sweetened Condensed Milk]. Prosiding Sains, Teknologi dan Kesehatan, 223-230.

Sa'adah, L. I. N., and Estiasih, T. 2015. Karakterisasi minuman sari apel produksi skala mikro dan kecil di kota Batu: Kajian Pustaka. [Characterization of Micro and Small Scale Apple Cider Drinks in Batu City: Literature Review]. Jurnal Pangan dan Agroindustri, 3(2): 374-380.

Sharma, S., Agarwal, N., \& Verma, P. 2011. Pigeon pea (Cajanus cajan L.): a hidden treasure of regime nutrition. Journal of Functional and Environmental Botany, 1(2), 91-101.

Seo, J. A., Oh, J., Kim, D. J., Kim, H. K., \& Hwang, Y. H. 2004. Making monosaccharide and disaccharide sugar glasses by using microwave oven. Journal of noncrystalline solids, 333(1), 111-114.

Tressl, R., \& Jennings, W. G. 1972. Production of volatile compounds in the ripening banana. Journal of agricultural and food chemistry, 20(2), 189-192.

Wardani, I. M. 2013. Pengaruh penambahan lidah buaya (Aloe vera Sp) terhadap sifat fisik dan kimia susu sapi segar dan susu kedelai. [The effect of adding aloe vera (Aloe vera $S p$ ) on the physical and chemical properties of fresh cow's milk and soy milk]. Jurnal Bioproses Komoditas Tropis, 1(1): 80-88.

Yanfang, Z., \& Wenyi, T. (2009). Flavor and taste compounds analysis in Chinese solid fermented soy sauce. African Journal of Biotechnology, 8(4):11-18.

Zhu, F. 2014. Influence of ingredients and chemical components on the quality of Chinese steamed bread. Food Chemistry, 163:154-162.

Zhao, C. J., Schieber, A., \& Gänzle, M. G. 2016. Formation of taste-active amino acids, amino acid derivatives and peptides in food fermentations-A review. Food Research International, 89, 39-47.

Received December $20^{\text {th }} 2020$, Revision January $31^{\text {st }} 2021$, Accepted for publication February $24^{\text {th }} 2021$.

Copyright (C) 2021 Published by FKIP - Unpatti, ISSN 2721-3110 